\title{
Can Knowledge Management Be Implemented in the Teaching of Medical Sciences?
}

\author{
Zahra Marzieh Hassanian¹, Mohammad Reza Ahanchian², Hossein Karimi-Moonaghi
}

${ }^{1}$ Department of Nursing, School of Nursing and Midwifery, Hamadan University of Medical Sciences, Hamadan, Iran ${ }^{2}$ Department off Educational Sciences, Faculty of Educational Sciences, Ferdowsi University of Mashhad, Mashhad, Iran ${ }^{3}$ Department of Medical Education, Faculty of Medicine, Mashhad University of Medical Sciences, Mashhad, Iran

\section{SUMMARY}

Universities play a vital role in social progress. Knowledge management (KM) is a kind of process which transforms data into knowledge and knowledge into capital. The aim of this paper is to investigate the use of KM in the field of education of medical sciences in order to help educators and students benefit from the knowledge present in the field of health sciences in a more meaningful and informed way.

To achieve the aim of this narrative review, the related Persian and English literature sources were carefully examined; first, the Internet and other data bases were searched for articles containing one or more of the following key words: knowledge, knowledge management, medical science and higher education. Then, the related articles were quickly scanned and useful information was extracted. The selected parts of the text were carefully studied and summarized by two researchers. After gaining a thorough comprehension of the subject, its different dimensions and aspects were described and compared.

As a process, the goal of $\mathrm{KM}$ in the field of medical sciences is to motivate the creation, sharing, storing and utilization of knowledge. Knowledge creation occurs by continually transforming tacit knowledge into explicit knowledge and vice versa. KM can be implemented in different areas of medical science including clinical practice. Knowledge managements system (KMS) plans are used to provide high quality, high value cost-effective care in medical science. Critical factors that influence the success of the implementation of KM in the field of medical education include culture, leadership and appropriate substructure. KM can be implemented for the development of medical education. KM is a tool which makes education and its practice intellectual, high quality and affordable. Implementation of $\mathrm{KM}$ is recommended in the field of medical education for effective health care delivery.

Key words: knowledge, implementation, knowledge management (KM), medical sciences

Corresponding author:

Hossein Karimi Moonaghi

e-mail: KarimiH@mums.ac.ir 


\section{INTRODUCTION}

Knowledge management $(\mathrm{KM})$ is referred to as an organizational activity implemented for creating an atmosphere in which data and information is transformed into knowledge and then to capital (1). The concept of KM in a broader sense is the efficient use of knowledge in order to enhance organizational capability and competitiveness (2). The academic community is considered to be the primary source of knowledge. Organizational competition is determined on the bases of the main competences and capabilities within the organization (3). Many reasons have often been cited by researchers for utilizing KM strategies, including: preventing knowledge loss (resulting from leave of absence, transfers and retirement), gaining more competitive advantage, reorganization, formal rectification of faults found during investigations and audits, continuous learning, synchronization with other organizations, catering to clients' needs, preventing a limited flow of knowledge and last but not the least, preventing the isolation of the department, individual or organization from taking place. Needless to add, universities and research institutes are academic communities which play a vital role in creating and transferring scientific knowledge; they are a critical source for social progress and development (4).

Medical science is a particularly rich area of knowledge but the depth of this knowledge is not used to satisfy the patient's needs and therefore does not exert significant influence on health outcomes (5). Kases et al. observed in their research that although a lot of in-depth data is processed in medical research, this information is not translated into action when treating patients (6).

Furthermore, explosive school programs, an emphasis on inter-professional education, a need for skills renewal and lifelong learning, the application of substitution therapy and an emphasis on high quality cost-effective health care, all in all, necessitate the implementation of KM (7). This need is further seen emphasized in the provision and growth of $\mathrm{KM}$ systems for enhancing the capacity in better-informed and evidence-based decision-making (8) and in the participation of clinical staff in policy-making, decisionmaking and planning plus to fulfill the need for capturing and sharing know-how (9). The importance of implementing $\mathrm{KM}$ approaches in health care delivery were emphasized Hsia et al (2) and transferring learning styles to a dynamic learning framework were highlighted by Kenner \& Fernandes (7). Lastly, the recognition of medical faculties as the basic source of new knowledge increases the necessity for the implementation of KM.

In the 1990s, discussions focused on the KM concept emerged in various fields ranging from business and librarianship to information services and Information Systems Management (10) however, despite a large number of studies undertaken in the field of medical science, not much literature is found to be focused on the implication of effective utilization of $\mathrm{KM}$ i.e. abundant profiting from intellectual capital. Hence, the present study was undertaken with the aim of providing a clear image of the effects of KM utilization in the educational field of medical science via a comprehensive list of research activities executed about this subject around the world.

\section{PROCEDURE}

This article is a narrative review that is comprised of four phases: searching (using specific strategies), collecting, checking and analyzing the articles.

Search strategies: All papers published between 1990 and 2013 in both Persian and English language that discussed the implementation of KM in the field of medical science and higher education were included. Science Direct, Elsevier, Web of Sciences (ISI), Embas, Ebsco, Ovid, Google Scholar and ProQuest data bases were searched using the key words, knowledge, knowledge management, medical science and higher education, both alone and combined. In addition to International databases, SID, IranMedex, IranDoc, MagIran, national databases were also used to collect related articles. The background research was done using the Iran Medical Sciences Digital Library portal.

The topic of KM has only recently emerged in academic and medical science articles, thus the number of studies focusing on KM implementation, particularly in medical science, was fairly limited.

Collecting phase: In the data collecting phase, a total of 325 articles were gathered, 54 of which were assessed for inclusion or omission of key issues and from among these, 21 articles were found to have a focus common with our research - the investigation of KM implementation in medical sciences. These were carefully scrutinized.

Checking and selecting phase: In this phase to identify the articles that appeared to be the most 
relevant, titles and abstracts found both in English and Persia were checked to be on the topic of implementation of KM in academic environments or in medical science. Unrelated articles were excluded. Coordination of the texts with our research objective was independently confirmed by two researchers though concealment of the authors' names was not possible. Repetitive articles and letters to the editor were excluded and in all, 21 articles were assessed. To achieve this, selected parts of the texts were precisely studied and summarized. After getting a gist of the subject-matter, the different aspects of the articles were compared and investigated.

Analyzing phase: The assessment of the material was done by two researchers, the results of which are shown in Table 1.

\section{RESULTS}

The results of the analysis of the above mentioned studies consisted of various dimensions and were categorized by their similarities into three distinct groups, discussed as follows:

1. The implementation of knowledge management at universities of medical sciences

2. Knowledge management and organizational learning

3. Requirements of knowledge management.

Table 1: Preliminary information extracted from articles on the implementation of KM in medical science

\begin{tabular}{|c|c|c|c|c|c|c|c|}
\hline Authors & $\begin{array}{c}\text { Tacit and } \\
\text { explicit } \\
\text { knowledge }\end{array}$ & $\begin{array}{c}\text { Application of } \\
\text { KM in higher } \\
\text { education }\end{array}$ & $\begin{array}{c}\text { Application of } \\
\text { KM in } \\
\text { healthcare } \\
\text { delivery }\end{array}$ & $\begin{array}{c}\text { Medical science } \\
\text { knowledge }\end{array}$ & $\begin{array}{l}\text { Application of } \\
\text { KM/ product }\end{array}$ & $\begin{array}{c}\text { Substructure } \\
\text { (Management, } \\
\text { technology, } \\
\text { culture) }\end{array}$ & $\begin{array}{c}\text { Organizational } \\
\text { learning and } \\
\text { learning } \\
\text { organization }\end{array}$ \\
\hline $\begin{array}{c}\text { Fril, Crily, } \\
\text { Jashapa, Pack, } \\
\text { Hum (11) }\end{array}$ & & & $\begin{array}{c}\text { Dynamicity of } \\
\text { the knowledge } \\
\text { available in the } \\
\text { article }\end{array}$ & & & & \\
\hline $\begin{array}{c}\text { Kenner and } \\
\text { Fernandez (8) }\end{array}$ & & $\begin{array}{l}\text { Transfer of } \\
\text { educational } \\
\text { models to } \\
\text { dynamic } \\
\text { learning } \\
\text { framework }\end{array}$ & & \begin{tabular}{|} 
Application of \\
advanced \\
educational \\
learning \\
management in \\
nursing \\
activities
\end{tabular} & $\begin{array}{l}\text { Competence- } \\
\text { based } \\
\text { education }\end{array}$ & & \\
\hline $\begin{array}{c}\text { Hisa, Lin, wu, } \\
\text { and } \\
\text { Tesaii (2) }\end{array}$ & & & $\begin{array}{c}\text { A framework } \\
\text { for designing } \\
\text { nursing KM } \\
\text { systems }\end{array}$ & & & Technology & \\
\hline Brook, Scot (9) & & & $\begin{array}{c}\text { Communication } \\
\text { skills for } \\
\text { nursing and } \\
\text { midwifery }\end{array}$ & & & $\begin{array}{c}\text { Technology and } \\
\text { tacit knowledge } \\
\text { transfer }\end{array}$ & \\
\hline \begin{tabular}{|c|} 
Kothari, \\
Rudman, \\
Dobbins, \\
Rouse, \\
Sibbald, \\
Edwards (12) \\
\end{tabular} & $\begin{array}{c}\text { Application of } \\
\text { tacit } \\
\text { knowledge }\end{array}$ & & $\begin{array}{c}\text { General } \\
\text { hygiene centers }\end{array}$ & & & culture & \\
\hline $\begin{array}{c}\text { Cheong-Lieng } \\
(13) \\
\end{array}$ & & & & $\begin{array}{l}\text { Clinical decision } \\
\text { support systems }\end{array}$ & & & \\
\hline Chen (14) & & & $\begin{array}{c}\text { Representing a } \\
\text { model for } \\
\text { nursing KM } \\
\text { practices }\end{array}$ & & & $\begin{array}{c}\text { The essentiality } \\
\text { of KM for } \\
\text { successful } \\
\text { development of } \\
\text { nursing } \\
\text { knowledge }\end{array}$ & \\
\hline
\end{tabular}




\begin{tabular}{|c|c|c|c|c|c|c|c|}
\hline $\begin{array}{l}\text { Kothari, } \\
\text { Hovanec, } \\
\text { Hastie, } \\
\text { Sibbald (15) }\end{array}$ & & & $\begin{array}{l}\text { Recognition of } \\
\text { business } \\
\text { strategies for } \\
\text { using in } \\
\text { healthcare }\end{array}$ & & \begin{tabular}{|c|} 
Educational \\
sessions, \\
communicatios \\
technology, \\
drawing \\
processes and \\
activities
\end{tabular} & & \\
\hline McCarthy (16) & & $\begin{array}{c}\text { Implement a } \\
\text { KM strategy/ } \\
\text { process via } \\
\text { critical success } \\
\text { factors of KM }\end{array}$ & & $\begin{array}{c}\text { Facilitating } \\
\text { research and } \\
\text { educational } \\
\text { activities }\end{array}$ & & $\begin{array}{l}\text { Technology } \\
\text { substructure }\end{array}$ & \\
\hline $\begin{array}{l}\text { Fehmida, } \\
\text { Reza (17) }\end{array}$ & $\begin{array}{c}\text { Extraction of } \\
\text { tacit } \\
\text { knowledge }\end{array}$ & & $\begin{array}{l}\text { Drawing tacit } \\
\text { with explicit } \\
\text { knowledge in } \\
\text { practice } \\
\text { guidelines }\end{array}$ & & $\begin{array}{c}\text { Guidelines for } \\
\text { clinical } \\
\text { activities }\end{array}$ & & \\
\hline $\begin{array}{c}\text { Pircher, } \\
\text { Pausits (18) }\end{array}$ & & $\begin{array}{c}\text { Provision of } \\
\text { academic } \\
\text { processes }\end{array}$ & & & $\begin{array}{c}\text { KM support } \\
\text { systems }\end{array}$ & $\begin{array}{c}\text { Communication } \\
\text { technology in } \\
\text { higher } \\
\text { education }\end{array}$ & \\
\hline $\begin{array}{l}\text { Khodaei, } \\
\text { Mousavi, } \\
\text { Zabihi (19) }\end{array}$ & & $\begin{array}{c}\text { Organizational } \\
\text { culture and } \\
\text { implementation } \\
\text { of KM }\end{array}$ & & & & $\begin{array}{c}\text { Organizational } \\
\text { culture and } \\
\text { implementation } \\
\text { of KM }\end{array}$ & \\
\hline $\begin{array}{c}\text { Han, Zhou, } \\
\text { Yang (20) }\end{array}$ & & \begin{tabular}{|c|}
$\begin{array}{c}\text { Broad access to } \\
\text { re-educational } \\
\text { resources }\end{array}$ \\
\end{tabular} & & & $\begin{array}{c}\text { Web-based } \\
\text { academic } \\
\text { databases }\end{array}$ & & \\
\hline $\begin{array}{c}\text { Wesa, } \\
\text { Sampson (21) }\end{array}$ & & & \begin{tabular}{|c|} 
Information- \\
seeking \\
behavior of \\
physicians \\
\end{tabular} & & & & \\
\hline Arasteh (22) & & \begin{tabular}{|c|} 
Creating, \\
disseminating, \\
storing and \\
using \\
knowledge \\
\end{tabular} & & & & & \\
\hline $\begin{array}{c}\text { Akhavan, } \\
\text { Saleh Avolia, } \\
\text { Jafari, Zareh } \\
\text { Mehrjerdi (23) }\end{array}$ & & $\begin{array}{c}\text { Representing a } \\
\text { model for } \\
\text { establishment } \\
\text { of KM in } \\
\text { universities }\end{array}$ & & & & $\begin{array}{c}\text { Management } \\
\text { and leadership } \\
\text { of } \\
\text { organizational } \\
\text { structure, } \\
\text { culture, } \\
\text { systems, } \\
\text { technology, } \\
\text { human resource } \\
\text { and function }\end{array}$ & \\
\hline $\begin{array}{c}\text { Ehsani, } \\
\text { Moshabaki, } \\
\text { Hadizadeh } \\
\text { (24) }\end{array}$ & & $\begin{array}{l}\text { Organizational } \\
\text { competence for } \\
\text { effective } \\
\text { implementation } \\
\text { of KM }\end{array}$ & & & & \begin{tabular}{|c|} 
The effect of \\
process, \\
structural, \\
cultural, \\
technological \\
and managerial \\
competence on \\
implementation \\
of KM \\
\end{tabular} & \\
\hline $\begin{array}{c}\text { Bratiano, } \\
\text { Vasilanch (25) }\end{array}$ & & & & $\begin{array}{c}\text { Knowledge } \\
\text { transfer }\end{array}$ & & & Clinical learning \\
\hline
\end{tabular}




\begin{tabular}{|c|c|c|c|c|c|c|c|}
\hline Cases et al. (6) & & & & $\begin{array}{c}\text { Combination of } \\
\text { advanced } \\
\text { knowledge in } \\
\text { biochemistry, } \\
\text { biology and } \\
\text { medicine fields }\end{array}$ & $\begin{array}{c}\text { Better } \\
\text { diagnosis, } \\
\text { treatment and } \\
\text { prediction }\end{array}$ & & \\
\hline Boatang (26) & $\begin{array}{c}\text { Integration of } \\
\text { tacit and } \\
\text { explicit } \\
\text { knowledge }\end{array}$ & & \begin{tabular}{|} 
Goal setting by \\
physician and \\
patient and \\
empowering \\
patients in \\
decision \\
making \\
\end{tabular} & & & & \\
\hline $\begin{array}{c}\text { Songsangyos } \\
(27)\end{array}$ & \begin{tabular}{|c} 
Explicit \\
knowledge \\
which \\
transforms the \\
tacit \\
knowledge \\
into the form \\
of reports \\
\end{tabular} & $\begin{array}{c}\text { Comparison } \\
\text { of knowledge } \\
\text { management } \\
\text { in higher } \\
\text { education }\end{array}$ & & & & $\begin{array}{l}\text { Technology } \\
\text { infrastructure }\end{array}$ & \\
\hline $\begin{array}{c}\text { Abdul } \\
\text { Rahman Zaki } \\
(28)\end{array}$ & & $\begin{array}{c}\text { Knowledge } \\
\text { framework } \\
\text { enhances the } \\
\text { learning } \\
\text { practices in } \\
\text { academia } \\
\end{array}$ & & & $\begin{array}{c}\text { Knowledge } \\
\text { framework (s) } \\
\text { enhances the } \\
\text { overall } \\
\text { learning }\end{array}$ & & $\begin{array}{l}\text { Knowledge } \\
\text { disseminating } \\
\text { and inner core } \\
\text { for academia }\end{array}$ \\
\hline Rowley (29) & $\begin{array}{c}\text { Knowledge } \\
\text { creation, } \\
\text { dissemination } \\
\text { and learning }\end{array}$ & & & & $\begin{array}{c}\text { Libraries, } \\
\text { electronic } \\
\text { collections of } \\
\text { learning } \\
\text { materials, } \\
\text { networks } \\
\end{array}$ & $\begin{array}{c}\text { Change in } \\
\text { culture and } \\
\text { values, } \\
\text { organizational } \\
\text { structures and } \\
\text { reward } \\
\end{array}$ & \\
\hline Gortner (30) & & & $\begin{array}{c}\text { Practice } \\
\text { affected } \\
\text { through } \\
\text { research, but } \\
\text { applications } \\
\text { did not occur }\end{array}$ & $\begin{array}{c}\text { Comments will } \\
\text { be made how } \\
\text { practice } \\
\text { affects through } \\
\text { research }\end{array}$ & & & \\
\hline $\begin{array}{c}\text { Orzano \& etc } \\
\qquad(31)\end{array}$ & & & \begin{tabular}{|c|} 
Knowledge \\
management \\
influences and \\
enhances \\
professional \\
disciplines \\
\end{tabular} & $\begin{array}{c}\mathrm{KM} \text { is a } \\
\text { beneficial } \\
\text { framework to } \\
\text { provide } \\
\text { quality care to } \\
\text { patients } \\
\end{array}$ & & $\begin{array}{l}\text { Technology } \\
\text { infrastructure }\end{array}$ & \\
\hline
\end{tabular}

Implementation of $\mathrm{KM}$ in universities of medical science

\section{Implementation of $\mathrm{KM}$ in Medicine}

The important components of KM strategy to be implemented in universities include creating, sharing and using knowledge (22). Proper well-timed use of up-to-date medical knowledge can improve patient and system outcomes, the benefits to be reaped from $\mathrm{KM}$ include patient-centered care, teamwork, safety, quality and cost efficiency (5). In medical education, stored knowledge can effectively safeguard from knowledge loss (32). Han et al. developed a new method which can collect and store re-educational resources from academic database networks and in case of being disconnected from the world-wide web, individuals could benefit from open retained sources (20). 
Implementation of KM and a framework for designing knowledge management systems (KMS) for nursing

Health care service organizations can deliver high quality, high value cost-effective care by using technology and its related strategies (7). The dimensions of KMS designs for nursing cover both the nursing process as well as KM technology. These systems that include electronic health records, medical information databases, prescription ordering and clinical decision support systems assist a better providing the needs of patients (2).

\section{field}

\section{Implementation of $\mathrm{KM}$ in health care}

As a successful implementation of $\mathrm{KM}$ in the field of healthcare has its own complexity, the following needs must be addressed first:

1. Designing a program and method for the implementation of KM.

2. Creating a suitable approach for accessing existing information and knowledge.

3. Collecting, selecting and classifying organizational knowledge and experiences.

4. Designing processes for sharing and disseminating information and knowledge.

5. Using gained knowledge to perform tasks.

6. Creating an assessment process for evaluating the quality of information (33)

\section{Knowledge management and organizational learning}

Learning organizations are defined as organizations skilled at creating, acquiring and transferring knowledge, and at modifying behaviors for reflecting new knowledge and insights (7). In such a case, higher education becomes an equivalent of a learning organization and knowledge starts getting shared on the basis of the same (15).

\section{$\mathrm{KM}$ and the creation of knowledge in medical science}

Creation of knowledge happens within the confines of routine activities; however, the main functions of universities are training and learning, and doing research work and offering services to society as a whole (34). Knowledge is created in universities through education, research, discussion and clinical learning (35). Knowledge creation can occur when knowledge is converted in four ways: externalization, internalization, combination and socialization (36). Knowledge is created through converting knowledge. Hassanian (2015) found that knowledge was converted through mind processes, individual and group reflection, praxis and research (37).

\section{$\mathrm{KM}$ and the transformation of tacit knowledge into explicit knowledge}

Tacit knowledge could be considered as the know-how and is a kind of learning that is embedded in the minds of individuals in an organization (38). When scrutinizing the methods used for learning theoretical subjects, it was found that the learning styles of students varied considerably but were uniquely modified and interpreted to match the situation, subject and level of education (39). Furthermore, a multiplicity of teaching styles was also seen to be predominant in clinical teaching (40). In all the multiple teaching and learning styles, tacit knowledge has the largest share in clinical education. In advanced models of evidence-based treatment, tacit knowledge can be converted to explicit knowledge (26). In a model designed by Fahmideh \& Reza, tacit knowledge is extracted from past cases and guidelines for clinical practice are developed through case-based reasoning and optimization of solutions (17).

\section{Execution of $\mathrm{KM}$ in sharing medical knowledge}

One of the objectives of KM implementation in universities is continuous learning through the process of sharing knowledge and experience among the individuals involved in the field of education and research (41). Trust is considered to be critical to the success of knowledge-sharing efforts in medical practicing environment, especially among doctors. Cooperation promotes a sense of worth in individuals and helps them balance out weak points with strong points (25). In medical sciences, the transfer of environmental knowledge occurs horizontally via learning activities such as observing, listening, questioning, sharing ideas, recommending, identifying guidelines and adapting behavioral patterns (42). 


\section{$\mathrm{KM}$ and its use in medical science/clinical knowledge}

Clinical learning plays an important role in medical education. As Karimi et al. suggested, clinical training is an essential component of the educational programs in medicine (43). When encountering a clinical question, physicians benefit from published sources and consultation with peers. Precise programs must be designed for representing essential information used for transferring and keeping knowledge up to date (21). Today, clinical decision support systems are available in the form of up-dated e-books which can be used easily for restoring information (13).

\section{Knowledge management for integrating theoretical and clinical knowledge}

Studies have shown that clinicians rarely put research knowledge into clinical practice (44), (33), (45). Gabby concluded that instead they rely on "mind-lines" or "collectively reinforced, internalized tacit guidelines". In other words, they use a combination of clinical guidelines and mind-lines to execute knowledge into action plans (1).

Thus, another objective of KM approaches in healthcare is the translation of knowledge to clinical practice and the development of a healthy outcome (5).

\section{KM and storing medical knowledge}

An organization's ability to store knowledge has a strong impact on later functions and can assist action planning and problem solving (46). Storing knowledge increases opportunities for exploiting knowledge and causes an increase in the surface and depth of learning both theoretical and clinical subjects (47). Knowledge is embedded in individuals, cultures, alterations and structures (48). Educators and students involve in teaching and learning activity by storing knowledge in subjective and objective forms (49). It can also be stored in educational materials stocks or retention bins to be reused later (16).

\section{Requirements of KM}

The requirements for a successful KM implementation must be provided for at universities, and this could directly facilitate innovation processes and decision making (18). Chen (14) suggested culture, leadership and technology to be the requirements for success (14). Culture, professional ethics, and responsibilityin the students is important, so affective objectives should be added to the curriculum and put into practice (49). Leadership in $\mathrm{KM}$ not only determines the prospects and strategies for the allocation of effective resources to knowledge sharing but also encourages a knowledge-sharing culture (16).

To increase the dynamicity of managerial systems in groups, an appropriate change in organizational structure and communication is required; this in turn helps managers use effective, reinforcing and supportive leadership styles (50). In order to build knowledge management aptitudes, the organization must improve an extensive frame that enables the various types of knowledge and communication. Several scopes of the technology infrastructure include intelligence, cooperation, dispersed learning, knowledge search, knowledge map, opportunity production, security (49). Ehsani et al. defined KM requirements as key competences while Akhavan et al defined them as vital factors leading to a successful KM implementation (24), (51).

\section{DISCUSSION}

By reviewing the articles, it was learnt that $\mathrm{KM}$ can be implemented in various medical fields. However, rigorous investigation needs to be undertaken into the different dimensions of $\mathrm{KM}$ implementation, in fields like medical education, nursing knowledge, managerial systems and healthcare; in the creation, sharing and application of knowledge, in organizational learning, in the transformation of tacit knowledge into explicit knowledge as well as in the requirements of KM.

To successfully implement KM in medical universities, the ideas of $\mathrm{KM}$ must be taken into account as an important principle when designing mission, prospectus, objectives and strategic plans in universities. If so not only would healthcare staff and people involved undertake education, research, care and treatment activities but would also capture, store, share and apply knowledge in a systematic way. In medical KM issues, knowledge is created through research and transferred through executing clinical and theoretical educational programs for adjusting and raising the standard of behaviors. Plus, an 
implementation of $\mathrm{KM}$ in medical science provides the opportunity for educators, students and staff to capture universal knowledge from their environment and apply it to the different dimensions of their professional activities, keep it up to date, share and create further knowledge in the process.

As health organizations are geographically sparsely-located, the implementation of KM in healthcare organizations has its own characteristics, which are as follows:

- Designing a comprehensive and detailed plan for implementing a KM initiative.

- Creating a proper approach to access knowledge.

- Running the process of collecting, selecting, classifying, organizing and disseminating information and knowledge in a wide area.

- KM implementation would build an integrated source of information and knowledge which can readily be shared and utilized in the system.

Organizational learning is another reward reaped from the implementation of KM. Organizational learning can be defined as an ability to develop awareness and understanding from experience and a tendency to investigate the cause of success and failure via feedback. Medical universities are knowledge-driven organizations which promote organizational learning and lead employees to a higher level of knowledge. This knowledge is reflected in correct decision-making and clinical practice, which is equivalent to creating value in medical science.

The level of knowledge in medical groups depends on the total amount of knowledge available and its level of exchange. Through externalization, healthcare staffs convert their tacit knowledge into explicit knowledge and then share and apply it to practice.

Outcomes of the studies on KM implementation demonstrated that clinicians usually rely on "mindlines" or "collectively reinforced, internalized tacit guidelines" in practice. As the role of tacit knowledge is more essential than explicit knowledge, clinicians combine the knowledge with midlines in their communications translating knowledge into practice.

The concept of KM has only recently attracted interest in the field of medical sciences thus the number of studies focusing on the same is quite limited. Leadership, organizational culture and structure, human resources, information technology and performance management are critical to the success of $\mathrm{KM}$ implementation. In this regard, multilevel KM strategies including training sessions, communication technologies and process mapping should be implemented.

\section{CONCLUSION}

KM can be applied to medical science. Universities build better knowledge utilization habits in medical environments through implementing the ideas of $\mathrm{KM}$ into their prospectus, objectives and strategic plans. By driving systematic KM implementation into medical science, every clinician, as an individual, can help promote the creation, capturing, sharing and putting of knowledge into action.

A lot of in-depth data is processed in medical research that must be put into action when treating patients. Sharing knowledge would help better use of dispersed knowledge and consequently facilitate the making of a better differential diagnosis and precognition as well as the delivery of a better cure.

The substructure of technology has been provided to all the medical science universities as a result of organizational and community development. Thus to implement a KM initiative, substructures such as management, leadership, culture and human resources must be taken into account. Universities must put more effort than any other organization into $\mathrm{KM}$ and organizational learning, and they must play a leading role in preserving one of the most important organizational capitals. 


\section{References}

1. Gabbay J, May A. Evidence based guidelines or collectively constructed "mindlines?" Ethnographic study of knowledge management in primary care. BMJ 2004; 329:1-5.

http://dx.doi.org/10.1136/bmj.329.7473.1013

2. Hsia TL, Lin LM, Wu JH, Tsai HT. A framework for designing nursing knowledge management systems. Interdiscip J Inf Knowl Manag 2006; 1: 13-21.

3. Bhatt G D. Knowledge management in organizations: Examining the interactions between technologies, techniques, and people. J Know Manag 2001; 5:68-75.

http://dx.doi.org/10.1108/13673270110384419

4. Tian J, Nakamori Y, Wierzbicki AP. Knowledge management and knowledge creation in academia: a study based on surveys in a Japanese research university. J Know Manag 2009; 13:76-92.

http://dx.doi.org/10.1108/13673270910942718

5. Abidi S R. Healthcare Knowledge Management: The Art of the Possible. D. Ria-o: Springer-Verlag Berlin Heidelberg; 2008. 1-20.

6. Cases M, Furlong LI, Albanell J, Altman RB, Bellazzi R, Boyer S. Improving data and knowledge management to better integrate health care and research. J Intern Med 2013; 274: 321-8.

http://dx.doi.org/10.1111/joim.12105

7. Kenner C, Fernandes JH. Knowledge management and advanced nursing education. Newborn Infant Nurs Revi 2001; 1:192-8.

http://dx.doi.org/10.1053/nbin.2001.24540

8. Peirson L, Ciliska D, Dobbins M, Mowat D. Building capacity for evidence informed decision making in public health: a case study of organizational change. BMC Public Health 2012; 12:1-13.

http://dx.doi.org/10.1186/1471-2458-12-137

9. Brooks F, Scott Knowledge work in nursing and midwifery: An evaluation through computermediated communication. Int J Nurs Stud 2006; 43:83-97.

http://dx.doi.org/10.1016/j.ijnurstu.2005.02.003
10. Mishra B, Bhaskar AU. Knowledge management process in two learning organizations. J Knowl Man 2011; 15:344-59.

http://dx.doi.org/10.1108/13673271111119736

11. Ferlie E, Crilly T, Jashapara A, Peckham A. Knowledge mobilisation in healthcare: A critical review of health sector and generic management literature. Soc Sci Med 2012; 74:1297-304. http://dx.doi.org/10.1016/j.socscimed.2011.11.042

12. Kothari A, Rudman D, Dobbins M, Rouse M, Sibbald S, Edwards N. The use of tacit and explicit knowledge in public health: a qualitative study. Implement Sci. 2012; 7.

http://dx.doi.org/10.1186/1748-5908-7-20

13. Lieng Ten C. Clinical knowledge management at the point of care. IeJSME 2012; 61 :S137-S41.

14. Chen C-W. Modeling and initiating knowledge management program using FQFD: A case study involving a healthcare institute. QualQuant. 2012; 46:889-915.

http://dx.doi.org/10.1007/s11135-011-9432-2

15. Kothari A, Hovanec N, Hastie R, Sibbald S. Lessons from the business sector for successful knowledge management in health care: A systematic review. BMC Health Serv Res. 2011; 11:173-84.

http://dx.doi.org/10.1186/1472-6963-11-173

16. McCarthy AF. Knowledge Management: Evaluating Strategies and Processes Used in Higher Education. (PhD thesis). Nova Southeastern University: Nova Southeastern University; 2006.

17. Fehmida H, AliRez S. Knowledge Management Framework to Operationalize Experiential Knowledge: Mapping Tacit Medical Knowledge with Explicit Practice Guidelines. Proceedings of National Conference on Emerging Technologies; 2004 December 18-19; SZABIST, Karachi, Pakistan. 93-99.

18. Pircher R, Pausits A. Information and Knowledge Management at Higher Education Institutions. Manag Inform Sys 2011; 6:8-16.

19. Khodaei M, Mousavi M, Zabihi MR. Readiness for Implementation of Knowledge Management 
in Universities; the Viewpoint of Faculty Members of Mashhad Islamic Azad University. Iranian Bimonthly of Education Strategies In Medical Sciences 2013; 6: 25-30. (Persian)

20. Han X, Zhou Q, Yang J. A Technical Mode for Sharing and Utilizing Open Educational Resources in Chinese Universities. KM\&EL 2011; 3:356-74.

21. Dawesa M, Sampson U. Knowledge management in clinical practice: a systematic review of information seeking behavior in physicians. Intl J Med Inform 2003; 71:9-15.

http://dx.doi.org/10.1016/S1386-5056(03)00023-6

22. Arasteh HR. An Examination of Knowledge Management Principal Factors in the University Setting: a case study. Interdisc StudHum J 2012; 2:1-13. (Persian)

23. Akhavan A, Saleh Avolia M, Jafari M, Zareh Mehrjerdi Y. Knowledge management strategies, critical Success factors, practices and universities performance. IAMS 2012; 7:115-141.(Persian)

24. Ehsani A, Moshabaki A, Hadizadeh M. Identification of key capabilities for effective implementation of knowledge management in hospitals with structural equation modeling approach. JHR 2012; 15: 58-68. (Persian)

25. Brătianu C, Vasilache S. Knowledge transfer in medical education from a teamwork perspective. Manag \& Market 2012; 7: 381-392.

26. Boateng, W. Knowledge Management in Evidence-Based Medical Practice: Does the Patient Matter? EJKM 2010; 8: 281 - 292. Available online at www.ejkm com.

27. Songsangyos P. The Knowledge Management in Higher Education in Chiang Mai: A Comparative Review. SociBehav Sci. 2012; 69:399-403. http://dx.doi.org/10.1016/j.sbspro.2012.11.426

28. Zaki A R, Zubairi S A . Role of Knowledge Management in Higher Education - A Qualitative Model. Interdis J Contem Res.Bus 2012; 4:1104-18.

29. Rowley J. Is higher education ready for knowledge management? Int J Edul Manag 2000; 14:325-33.

http://dx.doi.org/10.1108/09513540010378978
30. Gortner SR. Knowledge development in nursing: Our historical roots and future opportunities. Nursing Outlook 2000; 48:60-7. http://dx.doi.org/10.1016/S0029-6554(00)90004-6

31. Orzano A J, McInerney C R, Scharf D, Tallia A F, F. Crabtree B F. A Knowledge Management Model: Implications for Enhancing Quality in Health Care. J Am Soc Inform SciTech. 2008; 59:489-505.

http://dx.doi.org/10.1002/asi.20763

32. Argote L, Beckman S L, Epple D. The persistence and transfer of learning in industrial settings. Manag Sci 1990; 36:140-54. http://dx.doi.org/10.1287/mnsc.36.2.140

33. Mattila LR, Eriksson E. Nursing students learning to utilize nursing research in clinical practice. Nurs Educ Today 2007; 27:568-76. http://dx.doi.org/10.1016/j.nedt.2006.08.018

34. Eardley A, Uden L. Innovative Knowledge Management: Concepts for Organizational Creativity and Collaborative Design. New York: Hershey; 2011: 300-008.

35. Bradley SF. Processes in the creation and diffusion of nursing knowledge: an examination of the developing concept of family-centred care. J Adv Nurs 1996; 23:722-7. http://dx.doi.org/10.1111/j.1365-2648.1996.tb00043.x

36. Nonaka I, Takeuchi H. The Knowledge Creating. New York: Oxford University Press; 1995.

37. Hassanian ZM, Ahanchian MR, Ahmadi S, Hossein Gholizadeh R, Karimi-Moonaghi $H$. Knowledge Creation in Nursing Education. Glob J Health Sci 2015; 7:44-55.

38. Zhao J. School knowledge management framework and strategies: The new perspective on teacher professional development. Comp HumBehav. 2010; 26:168-75. http://dx.doi.org/10.1016/j.chb.2009.10.009

39. Karimi Moonaghi H, Dabbaghi F, Oskouie F, Vehvilä,inen-Julkunen K.Learning Style in Theoretical Courses: Nursing Students' Perceptions and Experiences. Iran J Med Edu 2009; 1:41-54. (Persian)

40. Karimi Moonaghi H, Dabbaghi F, Oskouie F, Vehvilä, inen-Julkunen K. Teaching style in 
clinical courses, a qualitative study. Bimon J Sab Univer Med Sci 2008; 15:182-191. (Persian)

41. Prusak 1. Knowledge and training: the missing connection. New York: Mc Graw-Hill; 2001:60-4.

42. Bosua R, Scheepers R. Towards a model to explain knowledge sharing in complex organizational environments. Knowl Management Res Prac 2007; 5: 93-109. http://dx.doi.org/10.1057/palgrave.kmrp.8500131

43. Karimi moonaghi H, Derakhshan A, Khajedalouei M, Dashti Rahmat abadi M, Binaghi T. Lived Clinical Learning Experiences of Medical Students: A Qualitative Approach. Iranian Journal of Medical Education, 2012; 6(11):635-647. (Persian)

44. Cheraghi MA. Theroizing to transforming of theory knowledge to practical domain process. Sci J Ham Nurs Midwifery Univer. 2008; 17:2434. (Persian)

45. Mattila L-R, Koivisto V, Laitila A H. Evaluation of learning outcomes in a research process and the utilization of research knowledge from the viewpoint of nursing students. Nurs Edu Today 2005; 25:487-95.

http://dx.doi.org/10.1016/j.nedt.2005.05.003

46. Olivera F. Memory systems in organizations: an empirical investigation of mechanisms for knowledge collection, storage and access. J Manag Stud 2000; 37: 811-32.

http://dx.doi.org/10.1111/1467-6486.00205

47. Schulte P A, Lentz T J, Anderson V P, Lamborg A D. Knowledge Management in Occupational Hygiene: The United States Example. Ann Occup Hyg 2004; 48:583-94. http://dx.doi.org/10.1093/annhyg/meh061

48. Walsh P, Ungson G R. Organizational Memory. Acad Manag Rev. 1991; 16:57-91.

49. Karimi moonaghi $\mathrm{H}$, Ahanchian MR, Hassanian ZM. A Qualitative Content Analysis of Knowledge Storage in Nursing Education System, Iran Red Crescent Med J 2014; 16:2-11.

50. E-Government: An Empirical Study. In Wimmer $\mathrm{M}$ A. Knowledge management in electronic government. Seoul, Korea: Nat Comp Agen; 2004 .281-293.

51. Hassanian M. Leadership Style of the Heads of the Departments in Hamadan. Iranian Journal of Medical Education 2004; 12:117-122. (Persian)

52. AkhavanSelah A, Volia M, Jafari M, Zareh Mehrjerdi Y. Knowledge management strategies, critical Success factors, practices and universities performance. IJMS 2012; 7:115-146. (Persian) 


\title{
Da li se upravljanje znanjem može primeniti u medicinskoj edukaciji?
}

\author{
Zahra Marzieh Hassanian'1, Mohammad Reza Ahanchian², Hossein Karimi-Moonaghi \\ ${ }^{1}$ Departman za edukaciju medicinskih sestara, Fakultet za sestrinstvo i akušerstvo, \\ Univerzitet medicinskih nauka Hamadan, Hamadan, Irak \\ ${ }^{2}$ Departman za edukacione nauke, Fakultet za edukacione nauke, \\ Ferdowsi Univerzitet $u$ Mashhadu, Mashhad, Iran \\ ${ }^{3}$ Departman za medicinsku edukaciju, Medicinski fakultet, \\ Univerzitet medicinskih nauka Mashhad, Mashhad, Iran
}

\section{SAŽETAK}

Univerziteti imaju ključnu ulogu u razvoju jednog društva. Upravljanje znanjem je vrsta procesa koji podatke pretvara u znanje, a znanje u kapital. Cilj ovog rada bio je da se ispita primena upravljanja znanjem u polju izučavanja medicinskih nauka kako bi edukatori i studenti na smisleniji i informativniji način imali koristi od znanja sadržanog u zdravstvenim naukama.

Da bi se ostvario cilj ovog pregleda literature, pažljivo su ispitivani relevantni izvori literature na persijskom i engleskom jeziku. Prvo su bile pretraživane internet i ostale baze podataka u cilju nalaženja radova koji su sadržali jednu ili više sledećih ključnih reči: znanje, upravljanje znanjem, medicinska nauka i visoko obrazovanje. Potom su pronađeni radovi brzo skenirani i izvučene su korisne informacije. Selektovani delovi teksta su pažljivo proučeni i sumirani od strane dva istraživača. Nakon sveobuhvatnog uvida u temu, opisane su i upoređene njene različite dimenzije i aspekti.

Cilj upravljanja znanjem, kao procesom, na polju medicinskih nauka je da motiviše kreiranje, deljenje, smeštanje i korišćenje znanja. Kreiranje znanja se odvija kroz kontinuirano pretvaranje prećutnog u eksplicitno znanje i obrnuto. Upravljanje znanjem se može primeniti u različitim oblastima medicinske nauke, uključujući i kliničku praksu. Planovi sistema upravljanja znanjem koriste se kako bi se omogućila visoko kvalitetna i isplativa zdravstvena nega. Najznačajniji faktori koji utiču na uspeh primene upravljanja znanjem na polju medicinske edukacije su kultura, vođstvo i odgovarajuća podstruktura. Upravljanje znanjem se može primeniti za razvoj medicinske edukacije. Ono predstavlja sredstvo koje edukaciju i njenu primenu čini intelektualnom, visoko kvalitetnom i dostupnom. Primena upravljanja znanjem se na polju medicinske edukacije preporučuje u cilju pružanja efektivne zdravstvene zaštite.

Ključne reči: znanje, primena, upravljanje znanjem, medicinske nauke 